\title{
ANSERJ
}

Vol. 5, No 2

Autumn / Automne 2014

pp. $65-85$

Canadian Journal of Nonprofit and Social Economy Research

Revue canadienne de recherche sur les OBSL et I'économie sociale

\section{Individual and Organizational Factors in the Interchangeability of Paid Staff and Volunteers: Perspectives of Volunteers}

\author{
Laurie Mook \\ Arizona State University \\ Eddie Farrell \\ St. Michael's Hospital \\ Antony Chum \\ London School of Hygiene and Tropical Medicine \\ Femida Handy \\ University of Pennsylvania \\ Daniel Schugurensky \\ Arizona State University \\ Jack Quarter \\ University of Toronto
}

\begin{abstract}
This study builds upon earlier studies of the degree of interchangeability between volunteers and paid staff in nonprofit organizations. While these earlier studies were from an organization perspective, this study is from the perspective of volunteers, and looks at individual and organizational characteristics in all types of organizations-nonprofits, for-profits, government agencies, and others. The findings indicate that $10.8 \%$ of volunteers reported replacing a paid staff member, 3.1\% permanently. Volunteers also reported being replaced by paid staff: $7.6 \%$ reported being replaced, $2.1 \%$ permanently. The study suggests that organizations utilize a co-production model and appear to interchange their paid staff and volunteers when needed in tasks requiring higher-level skills.
\end{abstract}




\section{RÉSUMÉ}

Cette étude se fonde sur des études antérieures qui portaient sur le niveau d'interchangeabilité entre Cette étude se fonde sur des études antérieures qui portaient sur le niveau d'interchangeabilité entre bénévoles et salariés dans des organismes à but non lucratif. Tandis que ces études antérieures adoptaient une perspective organisationnelle, cette étude-ci adopte celle des bénévoles et examine les caractéristiques individuelles et organisationnelles de toutes sortes d'organisations-à but non lucratif, à but lucratif, gouvernementaux et coopératifs. Elle se fonde sur deux sous-échantillons provenant d'une enquête aléatoire par téléphone avec 768 individus provenant de partout au Canada. Les résultats indiquent que 10,8\% des bénévoles disent avoir remplacé un salarié, $3,1 \%$ en permanence. Les bénévoles disent d'autre part que des salariés les ont remplacés : 7,6\% ont ainsi été remplacés par des salariés, $2,1 \%$ en permanence. L'étude semble montrer que les organisations utilisent un modèle de co-production et paraissent échanger leurs salariés et bénévoles au besoin pour des tâches requérant des habiletés de haut niveau.

Keywords / Mots clés : À but non lucratif; Bénévoles; Salariés

\section{INTRODUCTION}

There is a growing body of literature that examines the prevalence of interchange between volunteers and paid staff and the characteristics related to this phenomenon in various settings, including hospitals (Handy, Mook, \& Quarter, 2008; Handy \& Srinivasan, 2005), nonprofit organizations (Chum, Mook, Handy, Schugurensky, \& Quarter, 2013; Handy et al., 2008), and public sector and government agencies (Brudney, 1990; Brudney \& Gazley, 2002; Brudney \& Kellough, 2000). A key driver for research on interchangeability is the concern that the substitution of paid staff by volunteers over the long-term could result in a decrease in paid jobs within an organization and thus be viewed as a form of labour exploitation. Then again, the substitution of volunteers by paid staff in the short-term may signal a restricted volunteer labour supply.

While previous studies (Brudney, 1990; Brudney \& Gazley, 2002; Brudney \& Kellough, 2000; Chum, Mook, Handy, Schugurensky, \& Quarter, 2013; Handy, Mook, \& Quarter, 2008; Handy \& Srinivasan, 2005) have illuminated some organizational and individual factors associated with the interchangeability of volunteer and paid staff, they 1) rely on convenience or purposive samples, 2) have an exclusive focus on either the nonprofit or public sector without comparisons across sectors, and 3) have not looked at the extent to which replacement is permanent or temporary. Drawing on a random sample of Canadian volunteers, this is the first study that investigates the human resource interchangeability phenomenon across nonprofit, for-profit, and public sectors to quantify and compare the extent to which temporary and permanent replacement of volunteers by paid staff (and vice versa) occurs in the Canadian context from the perspective of the volunteer. In addition, this is the first 
time a study has explored the volunteer's perception of whether the volunteer/paid staff interchange is ethical or not. The recent trend in the literature on "volunteerability" has emphasized that volunteer labour can best be deployed if we better understand the volunteer's perspective (Haski-Leventhal, Meijs, \& Hustinx, 2010; Meijs, Tschirhart, Ten Hoorn, \& Brudney, 2009). Given the value of volunteers to organizations, it is important to understand their perspectives on the interchange between volunteer and paid labour, as it can impact their satisfaction and eventually their retention and recruitment.

\section{LITERATURE REVIEW}

Interchangeability between volunteer and paid staff has been examined in various contexts, including hospitals, nonprofit organizations, and the public sector. One study looked at hospitals (Handy \& Srinivasan, 2005) and another at Ronald McDonald House (Haski-Leventhal, Hustinx, \& Handy, 2011). The first study found that in hospitals, it is not always viable to replace paid staff dealing with direct medical services with volunteers for legal reasons. In programs such as Ronald McDonald House, the tasks that volunteers perform are not those that could be feasibly done by paid staff on a permanent basis.

A study of Canadian nonprofits found that the interchange of volunteers and paid labourers was widespread among nonprofit organizations, but that it was limited to a specific set of tasks related to customer service and to tasks requiring general skills (Chum et al., 2013). This accounted for about one-eighth of all tasks in one study (Handy et al., 2008) and about one-quarter of tasks in another (Chum et al., 2013). The study by Femida Handy, Laurie Mook, and Jack Quarter (2008) relied on a national survey of 661 Canadian nonprofits and was augmented by two case studies of two Canadian hospitals, while the one by Antony Chum, Laurie Mook, Femida Handy, Daniel Schugurensky, and Jack Quarter (2013), surveyed 836 nonprofits across Canada.

Both studies identified a wide range of volunteer/paid staff interchange among organizations, with some organizations not interchanging any tasks and others interchanging nearly all tasks. In addition, the variables associated with interchangeability of tasks varied in the two studies. The first study (Handy et al., 2008) did not systematically explore these factors, but noted that important determinants of whether tasks were interchanged were "the historical precedents of who has done the task traditionally ... [and] the degree of unionization and the regulations in collective agreements" (p. 16). The importance of these variables was particularly evident in the hospital case studies examined by the authors. The second study (Chum et al., 2013) explored the organizational-level variables associated with interchangeability more systematically and found that the three most significant predictors of greater interchange in nonprofit organizations were: 1) having a greater number of paid staff (reflecting organization size); 2) being a religious congregation; and 3) having an increase in the workload of paid staff. 
Studies on the public sector demonstrate a form of co-production in which varying degrees of paid and volunteer labour are combined (Brudney, 1990; Brudney \& Gazley, 2002; Brudney \& Kellough, 2000). While this interpretation may be suitable for some types of activities, it does not address the social significance of organizations using volunteers to replace paid staff. Femida Handy and Jeffrey Brudney (2007) focused on the economic factors involved in interchange decisions, such as the marginal costs and productivity of each type of labour. However, the existing research does not examine the factors involved in who gets interchanged, except in a general cost/benefit framework.

To the best of our knowledge, there has been no research on individual volunteers that examines their perceptions of the extent to which they replace paid staff or are replaced by paid staff. Thus, we embarked on this research with the purpose of examining the interchange of paid staff and volunteers from the perspective of the volunteer. In order to do so, we explored five research questions that have been overlooked in previous studies:

1. How prevalent is the replacement of a) paid staff by volunteers and b) volunteers by paid staff? Do rates of interchange vary according to organizational or individual factors?

2. What proportion of the replacement of a) paid staff by volunteers and $b$ ) volunteers by paid staff was permanent rather than temporary?

3. From the volunteer's perspective, what are the reasons why organizations are replacing paid staff and/or volunteers? Do these reasons differ for those who were permanently or temporarily replaced?

4. For volunteers who replaced paid staff or were replaced by paid staff, how many considered this interchange to be unfair/unethical? Does the opinion differ between volunteers who replaced employees permanently versus temporarily?

5. What are the organizational and individual factors affecting the replacement of a) paid staff by volunteers and $b$ ) volunteers by paid staff?

The purpose of this study was to extend existing research by comparing interchangeability across multiple contexts (e.g., nonprofit, for-profit, government), and to examine interchangeability from the perspective of volunteers.

\section{METHODS}

A Canadian cross-sectional survey was administered by telephone between December 2011 and August 2012. Individuals were selected from a randomly generated sample obtained from a national online phone directory, which contains aggregated information of residential land- and mobile-based numbers from publically available local telephone records for published telephone listings across Canada. To generate the sample, a python script 


\section{Mook, Farrell, Chum, Handy, Schugurensky, \& Quarter (2014)}

was used to randomly pull numbers from the database by each area code across Canada. In total, 20,000 phone numbers were obtained, with the number of listings roughly proportionate to the population by province. Out of the 20,000 numbers, around 2,100 individuals agreed to do the survey. A pre-screening question was asked: "in the past 12 months, have you volunteered?" to which 1,024 individuals answered "yes." The interviews were fully completed by 768 individuals resulting in a response rate of $75 \%$. All participants were 16 years of age or older and had volunteered in the past 12 months. The interviews, which lasted between 30 to 45 minutes, were conducted over the phone by trained interviewers who spoke both English and French. The Research Ethics Board at the University of Toronto provided approval for the study, and participants were asked to grant oral consent before commencing the interview.

As we were examining the replacement of paid staff by volunteers and the replacement of volunteers by paid staff, we excluded 211 participants $(27.5 \%)$ who reported that there were no paid staff members at the organization where they volunteered. To address our first research question (the prevalence of replacement of paid staff by volunteers) we asked survey participants the following two questions: 1) "In the past 12 months, for the organization you volunteered at the most, have you ever replaced a paid staff member?" 2) "In the past 12 months, for the organization you volunteered at the most, have you ever been replaced by a paid staff member?" Since we are doing two separate outcomes for this study, we separated the sample sizes into two groups. For the volunteers who reported replacing a paid staff member, we excluded 37 individuals who responded "unsure" to the response choices given ("yes," "no," or "unsure"), which left us with a final sample size of 520 participants for outcome 1. For outcome 2-volunteers who reported being replaced by a paid staff member-we removed 30 participants who responded "unsure," giving us a final sample size of 527.

In order to improve the representativeness of our data set, we assigned weights, a recommended practice in doing national surveys (Lohr, 1999; Pfeffermann, 1996). Probability weights were created based on the results of the 2010 Canada Survey of Giving, Volunteering and Participating (CSGVP) to address a potential selection bias within our data due to unlisted telephone numbers (Statistics Canada, 2012). These weights are used to reference the Canadian population of volunteers and we discovered, using a descriptive analysis, that our sample was either over- or under-represented by the following characteristics: gender, age, and province of residence. Probability weights were then constructed from those three socio-demographic characteristics. A value of one translates to an equal proportion between the representation of our data set and the Canadian population of volunteers, while a deviation may represent either an over- or under-representation. By weighting our sample, we maintain that our data are representative of the target population.

For our survey, we asked questions with regards to the participants' socio-demographic status, along with the amount of hours they volunteered and where they volunteered. We used questions from the CSGVP, a validated survey developed by Statistics Canada that reports on various aspects of volunteering across Canada. In addition, we asked questions that investigate the interchange between paid staff and volunteers. 
In almost one-fifth of cases, one or more of the dependent or independent variables of interest were missing due to survey non-response, with the question regarding net family income most frequently skipped (17.7\%). To account for the missing data we used multiple imputations-a highly recommended state-of-the-art methodological solution for replacing missing data (Rubin, 2004; Schafer \& Graham, 2002). We used multiple imputations by chained equations (MICE) to generate 50 complete datasets reflecting data collected on 50 random occasions. We then executed MICE on IVEware (Raghunathan, Solenberger, \& Van Hoewyk, 2002). After the MICE procedure, we used the MI analyze procedure (PROC MIANALYZE) in SAS 9.3 to simultaneously analyze the 50 data sets. The program generated pooled estimates and standard errors for all analyses in this study.

\section{FINDINGS}

We present our findings in two sections. We first present the results to our five research questions for volunteers who reported replacing paid staff. Then we report the results for volunteers who reported being replaced by paid staff.

\section{Results for volunteers replacing paid staff}

1. How prevalent is the replacement of volunteers by paid staff? Do rates of interchange vary according to organizational or individual factors?

In response to the first question, which examines the prevalence of replacement, we found that $10.8 \%$ of the volunteers $(n=56)$ reported that they replaced a paid staff member, with a $95 \%$ confidence interval $(\mathrm{Cl})$ of $7.9 \%$ to $12.9 \%$ estimated from 1,000 bootstrap samples (i.e., resampling with replacement from the original sample). When looking at different types of organizations, replacement of paid staff by volunteers was highest in for-profit organizations $(13.8 \%)$, followed by government $(11.3 \%)$, and nonprofits $(9.2 \%)$. However, there was no significant statistical difference between the three groups.

Table 1 examines the sample characteristics of participants who volunteered at organizations with paid staff, and includes respondents who replaced a paid staff member. To examine whether or not there is a significant relationship between each of the individual-level and organizational-level predictors and both types of replacement, the bivariate odds have been reported.

In terms of organizational factors, in addition to organization type reported in the first research question, we looked at organization field and the size of the paid workforce. We found a range of rates for the replacement of paid staff reported by volunteers across the different types of organization. In particular, education-related organizations had the lowest rate of replacement $(5.1 \%)$ while religious organizations had the highest $(30.2 \%)$. 
For the replacement of paid staff by volunteers, religious $(p<0.01)$ and recreation $(p<0.05)$ organizations had significantly higher rates compared to social services.

In regard to the size of an organization, volunteers from medium-sized organizations (from 6 to 20 paid staff) had a replacement rate of $17.7 \%$ and were significantly more likely to replace a paid staff member compared to very large organizations (over 50 staff) $(p<0.05)$.

In terms of individual-level characteristics, the data in Table 1 show that while a volunteer's gender or education level were not found to be significantly associated with replacement, the complexity of the tasks they undertook was. We found that $29.3 \%$ of volunteers who engaged in highly skilled tasks reported replacing a paid staff member $(p<0.001)$. This rate is significantly higher than those who were engaged in general-level tasks, with only $4.9 \%$ replacing a paid staff member, or board-level tasks, with $8.5 \%$ reporting replacing paid staff. Furthermore, we found those who volunteered more hours to be significantly more likely to report replacing a paid employee. This significant association was more likely for those who had volunteered more than 210 hours in the previous 12 months as compared to those who volunteered 40 or fewer hours $(p<0.001)$ in the same period. Additionally, two groups of volunteers-those not in the labour force (including volunteers who were

\section{Table 1: Sample characteristics and rates of individuals who volunteer at organizations with paid staff for outcome 1: Volunteers replacing paid staff (weighted $N=520)^{3}$}

\begin{tabular}{|c|c|c|c|c|}
\hline & \multirow[b]{2}{*}{ Total } & \multicolumn{2}{|c|}{$\begin{array}{l}\text { OUTCOME 1: } \\
\text { In the past } 12 \text { months, have you } \\
\text { replaced a paid staff member? }\end{array}$} & \multirow[t]{2}{*}{$\begin{array}{l}\text { Bivariate odds of paid } \\
\text { staff replacement (yes } \\
\text { versus no) }\end{array}$} \\
\hline & & No & Yes & \\
\hline Total & 520 & $464(89.2 \%)$ & $56(10.8 \%)$ & \\
\hline \multicolumn{5}{|c|}{ Organization-level characteristics } \\
\hline \multicolumn{5}{|c|}{ Organization type } \\
\hline Nonprofit ${ }^{1}$ & 403 & $366(90.8 \%)$ & $37(9.2 \%)$ & - \\
\hline For-Profit & 29 & $25(86.2 \%)$ & $4(13.8 \%)$ & 1.473 \\
\hline Government & 62 & $55(88.7 \%)$ & $7(11.3 \%)$ & 1.289 \\
\hline Other & 7 & $7(100.0 \%)$ & $0(0.0 \%)$ & 0.944 \\
\hline
\end{tabular}




\begin{tabular}{|c|c|c|c|c|}
\hline \multicolumn{5}{|l|}{ Organization field } \\
\hline Culture & 71 & $65(91.5 \%)$ & $6(8.5 \%)$ & 1.022 \\
\hline Health & 118 & $110(93.2 \%)$ & $8(6.8 \%)$ & 0.851 \\
\hline Religion & 38 & $28(73.7 \%)$ & $10(26.3 \%)$ & $4.082^{\star *}$ \\
\hline Education & 102 & $95(93.1 \%)$ & $7(6.9 \%)$ & 0.862 \\
\hline Recreation & 59 & $47(79.7 \%)$ & $12(20.3 \%)$ & $2.885^{\star}$ \\
\hline Unsure & 25 & $21(84.0 \%)$ & $4(16.0 \%)$ & 1.885 \\
\hline Social Services ${ }^{1}$ & 105 & $96(91.4 \%)$ & $9(8.6 \%)$ & --- \\
\hline \multicolumn{5}{|l|}{ Size of paid workforce } \\
\hline Fewer than 5 & 129 & $118(91.5 \%)$ & $11(8.5 \%)$ & 2.218 \\
\hline $6-20$ & 198 & $163(82.3 \%)$ & $35(17.7 \%)$ & $5.068^{* *}$ \\
\hline $21-50$ & 84 & $78(92.9 \%)$ & $6(7.1 \%)$ & 1.700 \\
\hline Over $50^{1}$ & 102 & $98(96.1 \%)$ & $4(3.9 \%)$ & -- \\
\hline \multicolumn{5}{|l|}{ Individual-level characteristics } \\
\hline \multicolumn{5}{|l|}{ Gender } \\
\hline Male $^{1}$ & 236 & $211(89.4 \%)$ & $25(10.6 \%)$ & -- \\
\hline Female & 284 & $252(88.7 \%)$ & $32(11.3 \%)$ & 1.080 \\
\hline \multicolumn{5}{|l|}{ Education } \\
\hline High school or less & 113 & $102(90.3 \%)$ & $11(9.7 \%)$ & 0.885 \\
\hline Some college or university & 72 & $65(90.3 \%)$ & $7(9.7 \%)$ & 1.094 \\
\hline $\begin{array}{l}\text { Postsecondary undergraduate } \\
\text { degree or diploma }\end{array}$ & 186 & $164(88.2 \%)$ & $22(11.8 \%)$ & 0.822 \\
\hline Graduate university degree $^{1}$ & 146 & $130(89.0 \%)$ & $16(11.0 \%)$ & -- \\
\hline \multicolumn{5}{|l|}{ Skill level of task } \\
\hline General level ${ }^{1}$ & 325 & $309(95.1 \%)$ & $16(4.9 \%)$ & -- \\
\hline
\end{tabular}


Mook, Farrell, Chum, Handy, Schugurensky, \& Quarter (2014)

\begin{tabular}{|c|c|c|c|c|}
\hline High skill level & 123 & $87(93.8 \%)$ & $36(29.3 \%)$ & $7.907^{\star \star *}$ \\
\hline Board member & 47 & $43(91.5 \%)$ & $4(8.5 \%)$ & 1.588 \\
\hline \multicolumn{5}{|c|}{ Hours volunteered in the past year } \\
\hline $1-40$ hours $^{1}$ & 133 & $125(94.0 \%)$ & $8(6.0 \%)$ & --- \\
\hline $41-100$ hours & 146 & $137(93.8 \%)$ & $9(6.2 \%)$ & 1.086 \\
\hline $101-210$ hours & 112 & $101(90.2 \%)$ & $11(9.8 \%)$ & 1.677 \\
\hline $211+$ hours & 128 & $100(78.1 \%)$ & $28(21.9 \%)$ & $4.409^{* * *}$ \\
\hline \multicolumn{5}{|l|}{ Employment status } \\
\hline Employed ${ }^{1,2}$ & 318 & $293(92.1 \%)$ & $25(7.9 \%)$ & --- \\
\hline Unemployed & 67 & $63(94.0 \%)$ & $4(6.0 \%)$ & 0.745 \\
\hline Not in labour force & 125 & $100(80.0 \%)$ & $25(20.0 \%)$ & $2.889^{* * *}$ \\
\hline \multicolumn{5}{|l|}{ Age } \\
\hline 15-24 years old & 103 & $96(93.2 \%)$ & $7(6.8 \%)$ & 0.915 \\
\hline 25-34 years old & 83 & $76(91.6 \%)$ & $7(8.4 \%)$ & 1.153 \\
\hline $35-64$ years old ${ }^{1}$ & 259 & $239(92.3 \%)$ & $20(7.7 \%)$ & --- \\
\hline $65+$ years old & 74 & $52(70.3 \%)$ & $22(29.8 \%)$ & $4.889^{\star \star *}$ \\
\hline
\end{tabular}

retired and on-leave from work) and those aged 65 and up-were also more likely to report that they had replaced paid staff (both at $p<0.001$ ).

2. What proportion of the replacement of paid staff by volunteers was a permanent rather than temporary replacement?

With regard to the second question, which asks what proportion of replacement was permanent rather than temporary, $28.6 \%(n=16)$ indicated a permanent replacement. The remaining $71.4 \%(n=40)$ of volunteers who had replaced paid staff stated that they did so temporarily. Out of our whole sample, representative of those who volunteered at organizations with paid staff, $3.1 \%$ (with a $95 \% \mathrm{Cl}$ of $1.0 \%$ to $3.5 \%$ ) reported permanently replacing a paid staff member. 


\section{Mook, Farrell, Chum, Handy, Schugurensky, \& Quarter (2014)}

3. From the volunteer's perspective, what are the reasons why organizations are replacing paid staff with volunteers? Do these reasons differ for those who were permanently or temporarily replaced?

About three-quarters (43 out of $56 ; 76.8 \%$ ) of the respondents who replaced paid staff indicated they did so to cover absences, with a significant difference between those who replaced an employee temporarily (31 out of 40; 77.5\%) and permanently ( 14 out of $16 ; 87.5 \%)(p<0.01)$. Almost a quarter (13 out of $56 ; 23.2 \%$ ) indicated the reason they replaced staff was because of budget cuts, and this was far more prominent for those who indicated that they were replacing paid staff permanently (11 out of 16 or $68.8 \%$ for permanent replacement versus 2 out of 40 or $5.0 \%$ for temporary replacement, $p<0.001$ ). A change in the organization was mentioned less frequently ( 7 out of $56 ; 12.5 \%$ ), but more for those who replaced temporarily ( 6 out of $40 ; 15.0 \%$ ) than permanently (1 out of $16 ; 6.3 \%$ ), although this difference was not statistically significant. Expansion of services was a reason indicated by a quarter of the respondents ( 15 out of $56 ; 26.8 \%$ ); it was mentioned by 6 out of 40 or $15.0 \%$ of those who replaced paid staff temporarily and by 9 out of 16 or $56.3 \%$ of those who replaced paid staff permanently $(p<0.01)$.

4. For volunteers who replaced paid staff, how many considered this interchange to be unfair/unethical? Does the opinion differ between volunteers who replaced employees permanently versus temporarily?

With regard to the fourth question, volunteers who replaced paid staff were asked whether they viewed such substitution as fair, using a 5 -point Likert scale from 1 (very unfair) to 5 (very fair). Overall, $7.1 \%$ of these volunteers felt that their replacing a paid staff member was unfair or very unfair. For those volunteers who indicated that they had temporarily replaced a paid staff member, $7.5 \%(n=3)$ felt it was unfair or very unfair; $12.5 \%(n=2)$ of volunteers who took over permanently felt this was unfair or very unfair.

\section{What are the organizational and individual factors affecting the replacement of paid staff by volunteers?}

Since our dependent variable is a dichotomous variable (whether volunteers replaced a paid staff member or not), and we have a highly stratified sample of zero-inflated binary data, we used exact logistic regressions, a method that is useful for analyzing small or unbalanced binary data with covariates (Mehta \& Patel, 1995), further examine whether or not volunteer characteristics and organizational factors affect rates of interchange.

Table 2 presents the estimate of the odds of the replacement of paid staff and volunteers. Only variables from Table 1 that were found to be significantly associated with both types of replacement were used in the models. 


\section{Table 2: Exact logistic regression to estimate the odds of volunteers replacing paid staff (weighted $N=520)^{3}$}

\begin{tabular}{|c|c|c|}
\hline & $\begin{array}{l}\text { Model 1: Organizational } \\
\text { factors }\end{array}$ & $\begin{array}{l}\text { Model 2: Organizational } \\
\text { factors and individual- } \\
\text { level covariates }\end{array}$ \\
\hline \multicolumn{3}{|c|}{ Organizational-level predictors } \\
\hline \multicolumn{3}{|c|}{ Organization type } \\
\hline Culture & 1.095 & 1.171 \\
\hline Health & .0961 & .0977 \\
\hline Religion & $3.957^{* *}$ & 2.501 \\
\hline Education & 1.164 & 1.129 \\
\hline Recreation & $3.046^{*}$ & 1.647 \\
\hline Unsure & 1.999 & \\
\hline Social services ${ }^{1}$ & --- & -- \\
\hline \multicolumn{3}{|c|}{ Size of paid workforce } \\
\hline Fewer than 5 & 1.999 & 3.275 \\
\hline $6-20$ & $4.391^{* *}$ & $6.021^{* *}$ \\
\hline $21-50$ & 1.665 & 2.237 \\
\hline Over $50^{1}$ & --- & -- \\
\hline \multicolumn{3}{|c|}{ Individual-level characteristics } \\
\hline \multicolumn{3}{|l|}{ Age } \\
\hline $15-24$ years old & --- & 0.967 \\
\hline $25-34$ years old & --- & 0.846 \\
\hline $35-64$ years old ${ }^{1}$ & --- & -- \\
\hline $65+$ years old & --- & 2.740 \\
\hline \multicolumn{3}{|c|}{ Hours volunteered in the past year } \\
\hline $1-40$ hours $^{1}$ & --- & -- \\
\hline $41-100$ hours & --- & 0.729 \\
\hline $101-210$ hours & --- & 1.194 \\
\hline $211+$ hours & --- & 1.364 \\
\hline \multicolumn{3}{|l|}{ Skill level of task } \\
\hline General level $^{1}$ & --- & -- \\
\hline Board member & --- & 1.327 \\
\hline High skill level & --- & $6.781^{* * *}$ \\
\hline \multicolumn{3}{|c|}{ Employment status } \\
\hline Employed $^{1}$ & --- & -- \\
\hline Unemployed & --- & 1.141 \\
\hline Not in labour force & --- & 0.971 \\
\hline
\end{tabular}


Model 1 (see Table 2) examines the multivariate association between organizational-level predictors and the odds of paid staff being replaced by volunteers. We found that recreation and religious organizations were positively associated with the odds of paid staff being replaced by volunteers when compared to social service organizations. There was a higher odds ratio $(\mathrm{OR})$ for recreation organizations (OR 3.046; $p<0.05)$ and higher odds for religious organizations (OR $3.957 ; p<0.01$ ). Also, organizations with 6 to 20 paid staff had higher odds of replacing paid staff with volunteers when compared to those that had 50 or more paid staff (OR $4.391 ; p<0.01$ ).

Model 2 (see Table 2) inserts both individual-level characteristics and organizational-level predictors into a fully adjusted multivariate model. After adjusting for the individual-level characteristics, the organizational field lost its significance, except that paid staff had higher odds of being replaced by volunteers in organizations with a paid workforce of 6 to 20 paid employees when compared to organizations with a paid workforce of over 50 (OR $6.021 ; p<0.01$ ). There was, however, an important individual finding: paid staff had higher odds of being replaced by volunteers who were engaged in high skill level tasks over those volunteers who were doing general level tasks (OR 6.781; $p<0.001)$.

\section{Results for paid staff replacing volunteers}

\section{Sample Characteristics}

We now turn to the results relating to the subsample of volunteers reporting whether or not paid staff replaced them. This subsample included 527 respondents. Female volunteers comprise $54.6 \%$ of this group, which is similar to the 2010 CSGVP national sample of volunteers (51.9\% female). As with the first subsample, the majority of volunteers held a postsecondary degree or higher (64.6\%), compared to $57.3 \%$ in the 2010 CSGVP. Most volunteers in this sample volunteered at nonprofit organizations (82.8\%) with health, social services, and education being the most predominant types of organizations. The majority of our sample $(63.1 \%)$ was employed in either part- or full-time jobs, which is similar to the 2010 CSGVP rate (61.3\%). Volunteers who were replaced by a paid staff member volunteered an average of 308 hours, and those who did not experience any replacement volunteered an average of 164 hours.

1. How prevalent is the replacement of volunteers by paid staff? Do rates of interchange vary according to organizational or individual factors?

Of the 527 respondents, $7.6 \%(n=38)$ reported that they had been replaced by a paid staff person, with a $95 \%$ confidence interval of $3.8 \%$ to $7.8 \%$. The bivariate odds were examined between organizational type and "volunteers who had been replaced by a paid staff' (see Table 3). When looking at different types of organizations, replacement of volunteers by paid staff was highest for the "Other" category ( $40.0 \%)$, followed by for-profits (13.8\%), nonprofits ( $5.6 \%)$, and government $(4.8 \%)$. Both the for-profit and government groups were not statistically different from nonprofits. 


\section{Table 3: Sample characteristics and proportion of individuals who volunteer at organizations with paid staff for outcome 2: Paid staff replacing volunteers (weighted $N=527)^{3}$}

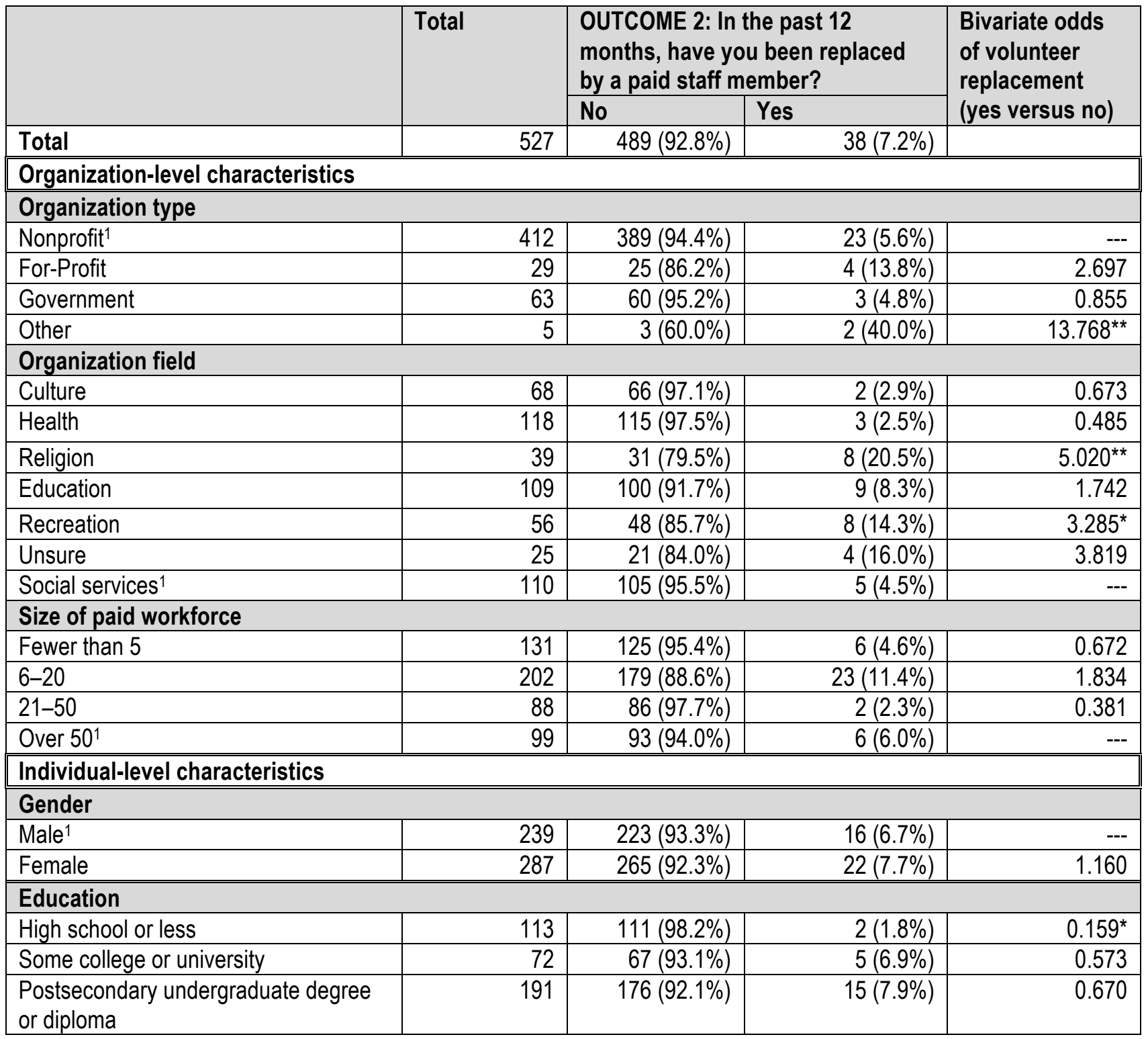




\begin{tabular}{|c|c|c|c|c|}
\hline Graduate university degree $^{1}$ & 147 & $131(89.1 \%)$ & $16(10.9 \%)$ & $-\cdots$ \\
\hline \multicolumn{5}{|l|}{ Skill level of task } \\
\hline General level $^{1}$ & 327 & $320(97.9 \%)$ & $7(2.1 \%)$ & \\
\hline High skill level & 125 & $98(78.4 \%)$ & $27(21.6 \%)$ & $12.047^{\star * *}$ \\
\hline Board & 51 & $45(88.2 \%)$ & $6(11.8 \%)$ & $4.435^{\star}$ \\
\hline \multicolumn{5}{|c|}{ Hours Vvolunteered in the past year } \\
\hline $1-40$ hours $^{1}$ & 131 & $125(95.4 \%)$ & $6(4.6 \%)$ & -- \\
\hline $41-100$ hours & 149 & $143(96.0 \%)$ & $6(4.0 \%)$ & 0.930 \\
\hline $101-210$ hours & 118 & $113(95.8 \%)$ & $5(4.2 \%)$ & 0.855 \\
\hline $211+$ hours & 129 & $108(83.7 \%)$ & $21(16.3 \%)$ & $4.077^{* \star}$ \\
\hline \multicolumn{5}{|l|}{ Employment status } \\
\hline Employed $^{1,2}$ & 326 & $312(95.7 \%)$ & $14(4.3 \%)$ & $-\cdots$ \\
\hline Unemployed & 69 & $68(98.6 \%)$ & $1(1.4 \%)$ & 0.451 \\
\hline Not in labour force & 122 & $100(82.0 \%)$ & $22(18.0 \%)$ & $4.750^{* * \star}$ \\
\hline \multicolumn{5}{|l|}{ Age } \\
\hline 15-24 years old & 105 & $102(97.1 \%)$ & $3(2.9 \%)$ & 0.359 \\
\hline $25-34$ years old & 86 & $84(97.7 \%)$ & $2(2.3 \%)$ & 0.352 \\
\hline $35-64$ years old 1 & 268 & $249(92.9 \%)$ & $19(7.1 \%)$ & $-\cdots$ \\
\hline $65+$ years old & 69 & $54(78.3 \%)$ & $15(21.7 \%)$ & $3.593^{* *}$ \\
\hline
\end{tabular}

In terms of organizational-level factors, we found a range of rates for "paid staff replacing volunteers" reported by volunteers. In particular, health-related organizations had the lowest rate of replacement $(2.5 \%)$ while religious organizations had the highest $(20.5 \%)$. For the replacement of volunteers by paid staff, religious and recreation organizations had significantly higher rates compared to social services. With regard to the size of an organization, medium organizations had an increased rate of replacement compared to very large organizations $(11.4 \%$ compared to $6.0 \%$ ), but the difference was not significant in our statistical test. Overall, there was no significant likelihood when examining the rate of replacement of volunteers by paid staff based on the size of the organization's workforce.

In terms of individual factors, there were no differences by gender. Compared to those with a postsecondary degree, respondents who had completed high school or less were significantly less likely to have been replaced by a paid staff person $(1.8 \%$ versus $10.9 \%, p<0.05)$. We found that $18.3 \%$ of volunteers who engaged in highly skilled tasks and $11.8 \%$ of volunteers performing board-level tasks reported being replaced by a paid staff member $(p<0.001)$. These rates are significantly higher than those who engaged in general-level tasks, with only $2.1 \%$ being replaced by a paid staff member $(p<0.001 ; p<0.05)$. Furthermore, we found those who volunteered more hours to be significantly more likely to report replacement. This significant association was more likely for those who volunteered more than 210 hours in the previous 12 months as compared to those 


\section{Mook, Farrell, Chum, Handy, Schugurensky, \& Quarter (2014)}

who volunteered 40 or fewer hours $(p<0.01)$. Additionally, two groups of volunteers-those not in the labour force (including volunteers who were retired and on-leave from work) and those aged 65 and up-were also more likely to report that they were replaced by paid staff ( $p<0.001$ and $p<0.01$ respectively).

2. What proportion of the replacement of volunteers by paid staff was a permanent rather than temporary replacement?

Of the volunteers who reported being replaced by a paid staff member, $28.9 \%(n=11)$ reported a permanent replacement and $71.1 \%(n=27)$ said that this replacement was only temporary. Out of our whole sample, representative of those who volunteered at organizations with paid staff, 2.1\% (with a 95\% confidence interval of $0.8 \%$ to $3.2 \%$ ) reported being permanently replaced by a paid staff member.

3. From the volunteer's perspective, what are the reasons why organizations are replacing volunteers with paid staff? Do these reasons differ for those who were permanently or temporarily replaced?

The volunteers who had been replaced by paid staff $(n=38)$ were also asked to give reasons as to why they had been replaced. For $55.3 \%$ of them $(n=21)$, it was due to a shortage of volunteers. For those who were permanently replaced $(n=11)$, this rate was $27.3 \%(n=3)$. For those temporarily replaced $(n=27)$ the rate was $66.7 \%(n=18)$. This was a significant difference with $p<0.05$. Others reported that volunteers did not possess the skills required for the tasks $(n=7 ; 18.4 \%)$. The rate for permanent replacement was $36.4 \%(n=4)$ and for temporary replacement it was $11.1 \%(n=3)$; however, this difference was not found to be statistically significant. Another reason for replacement of volunteers by paid staff was that the organization received more money for paid staff $(n=8 ; 21.1 \%)$. For permanent replacements, this rate was $45.5 \%(n=5)$; for temporary replacements it was $11.1 \%(n=3)$, a significant difference $(p<0.05)$.

4. For volunteers who replaced paid staff, how many considered this interchange to be unfair/unethical? Does the opinion differ between volunteers who permanently replaced a paid staff member versus those who replaced one temporarily?

With regard to this question, volunteers who were replaced by paid staff $(n=38)$ were asked whether they viewed such substitution as fair, using a 5-point Likert scale from 1 (very unfair) to 5 (very fair). Overall, 18.4\% $(n=7)$ of volunteers felt that their replacement of a paid staff member was unfair or very unfair. For those volunteers who indicated that a paid staff member had temporarily replaced them $(n=27), 11.1 \%(n=3)$ felt it was unfair or very unfair, compared to $36.4 \%(n=4)$ of volunteers who were permanently replaced $(n=11)$. Overall, the difference between the two groups as to the fairness of the replacement was not statistically significant. 
5. What are the organizational and individual factors affecting the replacement of paid staff by volunteers?

Table 4 examines the variables from the bivariate analysis items in Table 3, which were found to have a significant association with regards to volunteers who had been replaced by a paid staff member. Model 1 in Table 4 examines organizational characteristics. In this model, when compared to nonprofit organizations, organizations in the category "other" had higher odds (OR 14.468; $p<0.01$ ) of replacing a volunteer with a paid staff member. Also, recreation organizations had higher odds $(\mathrm{OR} 3.541 ; p<0.05)$ of replacing volunteers when compared to social services.

Table 4: Exact logistic regression to estimate the odds of paid staff replacing volunteers (weighted $N=527$ )

\begin{tabular}{|c|c|c|}
\hline & $\begin{array}{l}\text { Model 1: } \\
\text { Organizational factors }\end{array}$ & $\begin{array}{l}\text { Model 2: } \\
\text { Organizational factors and individual- } \\
\text { level covariates }\end{array}$ \\
\hline \multicolumn{3}{|l|}{ Organizational-level predictors } \\
\hline \multicolumn{3}{|l|}{ Organization field } \\
\hline Nonprofit ${ }^{1}$ & -- & -- \\
\hline For-Profit & 1.545 & 3.002 \\
\hline Government & 0.704 & 0.761 \\
\hline Other & $14.468^{* *}$ & 6.705 \\
\hline \multicolumn{3}{|l|}{ Organization type } \\
\hline Culture & 0.623 & 0.391 \\
\hline Health & 0.466 & 0.337 \\
\hline Religion & 1.488 & 1.854 \\
\hline Education & 1.285 & 1.707 \\
\hline Recreation & $3.541^{*}$ & 1.589 \\
\hline Unsure & 3.498 & 2.697 \\
\hline Social services $^{1}$ & -- & -- \\
\hline \multicolumn{3}{|l|}{ Individual-level characteristics } \\
\hline \multicolumn{3}{|l|}{ Education } \\
\hline High school or less & --- & $0.121^{*}$ \\
\hline Some college or university & --- & 0.454 \\
\hline $\begin{array}{l}\text { Postsecondary undergraduate degree } \\
\text { or diploma }\end{array}$ & --- & 0.390 \\
\hline
\end{tabular}


Model 2 (see Table 4) examines both the significant organizational factors and individual-level covariates with the replacement of volunteers by paid staff members. When the individual factors are added, the significance of the organizational factors disappears. In this case, three individual factors emerge as significant. The odds are lower for those with a high school or less education compared to those with a graduate degree (OR 0.121; $p<0.05)$. Highly skilled volunteers had higher odds of being replaced than volunteers performing tasks at a general level $(\mathrm{OR} 6.677 ; p<0.001)$, as did those not in the labour force compared to those who were employed (OR $3.578 ; p<0.05)$.

\section{DISCUSSION}

One of our main findings was that $10.8 \%$ of the Canadian volunteers who participated in our survey reported that they replaced a paid staff member. These replacements were predominantly temporary, but $3.1 \%$ of the sample reported permanently replacing a paid staff member. Overall, volunteers did not feel that replacement was unfair.

Interestingly, $7.6 \%$ of volunteers reported that they had been replaced by paid staff, and of the total sample, $2.1 \%$ reported that the replacement was permanent. The social importance of a volunteer being replaced by a paid staff member cannot be compared to a paid staff being replaced by a volunteer, but the fact that both of these practices were reported and at not dissimilar rates may suggest that nonprofit organizations, in particular, view their human resources, whether paid or unpaid, as interchangeable, and move these human resource components about according to organizational need. This finding is consistent with previous studies, using the organization as the unit of analysis (Chum et al., 2013; Handy et al., 2008).

To a degree, the data from this study could lead to the interpretation that paid staff and volunteers are like interchangeable parts, not as a general operating strategy but rather one to help the organization cope in times of need. The evidence to support this is underlined by the point that those being interchanged tended to be engaged in high-skill tasks, suggesting that they were an integral part of the organization. This interpretation is consistent with the co-production model (Brudney, 1990; Brudney \& Gazley, 2002; Brudney \& Kellough, 2000), which views paid and unpaid human resources as a collaborative arrangement that organizations utilize to meet their objectives. The Brudney et al. studies were undertaken with public sector organizations; our study involves volunteers predominantly with nonprofit organizations. In those organizations where paid staff replaced volunteers, the volunteers were more likely to be not in the labour force than employed. These volunteers were mostly retirees, perhaps stepping in as pro bono consultants for organizations re-evaluating their strategic direction or successfully increasing their funding in order to grow. This may be reflective of the increased emphasis on older adult volunteers wanting to give back in their retirement stage (Cook \& Speevak Slodowski, 2013; Lapierre, 2013). 
In general, we found that larger organizations were less likely to replace paid staff with volunteers. Although the reasons for this were unclear, one could speculate that they have the resources to address their needs with paid staff and use volunteers in relatively peripheral or niche roles. This interpretation is consistent with some of our findings that indicated that the tendency to interchange human resources was reported as being for such needs as covering absences, expansion of services, budget cuts, and changes in the organization. The data for budget cuts as a reason for replacement were of interest because they were far more prominent for those who indicated that they were replacing paid staff permanently $(68.0 \%$ versus $5.0 \%$ for those replacing paid staff temporarily). If budget changes are indeed a driver of organizations interchanging paid staff and volunteers, and assuming that financial fluctuations are not uncommon among nonprofit organizations, it might be that having a pool of volunteers to work with paid staff, as in the co-production model, gives organizations flexibility they would otherwise lack. Therefore, co-production arrangements may come about because they offer flexibility for organizations with unpredictable resources, not because they represent a workplace ideal. Assuming that this is the case, one might expect that, for organizations with relatively stable finances, the tendency to interchange paid staff and volunteers may be far less than it is for organizations with greater financial unpredictability.

\section{Summary and suggestions for further research}

This study is part of a broader research project on volunteers and paid staff in organizations, and builds on previous studies. Unlike those studies, this one used individual volunteers as its unit of analysis rather than nonprofit organizations. As with many surveys, a limitation of the findings is that they are based on the selfreporting of volunteers, and this should be kept in mind.

As far as we know, this study is the first of its kind to attempt to determine the degree to which volunteers and paid staff are being interchanged (volunteers replacing paid staff and vice versa) and the individual and organizational characteristics related to this phenomenon by collecting data from individual volunteers. The responses to the research questions shed some light on the extent of the interchange, the type of organizations where interchange is more likely to occur, and the profile of the volunteer who is more likely to be interchanged. This study also opens several new questions that could be explored in further research.

First, there is a need to explore the relationship between the volunteer/paid staff interchange and organizational type. As noted above, larger organizations appear to be much less likely to interchange. Qualitative research is necessary to probe the explanations for this, examining whether larger organizations have certain characteristics that affect the likelihood of labour interchange.

A second recommendation for research is to explore why volunteers who engage in high-skills tasks are more likely than those who engage in low-skills tasks to replace paid staff and vice versa. A third suggestion for future research is to explore the characteristics of the specific jobs and the paid staff that are being interchanged, and 
the reasons for short-term and long-term interchange. A fourth suggestion is to look more closely at the characteristics of those volunteers not in the labour force, and the relationship of this factor to the replacement of volunteers by paid staff, as this was a significant factor in the regression analysis.

Finally, we strongly suggest that this issue be examined further through the representative sample studies of volunteering conducted by Statistics Canada and by other researchers, particularly with a focus on how this issue might differ for nonprofits, for-profits, and government agencies. This issue takes on greater importance because of the growth of unpaid internships and accumulating evidence that basic labour laws do not cover them. In brief, we believe that this phenomenon deserves more attention from researchers, from policymakers, and from the voluntary sector alike.

\section{ACKNOWLEDGEMENTS}

The authors would like to acknowledge the support of the Social Science and Humanities Research Council of Canada, Standard Research Grant \#487026.

\section{NOTES}

1. Reference category: selected due to being the largest category and/or had no association with interchange.

2. Employed includes both part-time and full-time employment.

3. ${ }^{*} p<0.05 ;{ }^{* *} p<0.01 ;{ }^{* * *} p<0.001$

\section{REFERENCES}

Brudney, J.L. (1990). Fostering volunteer programs in the public sector. San Francisco, CA: Jossey-Bass.

Brudney, J.L., \& Gazley, B. (2002). Testing the conventional wisdom regarding volunteer programs. Nonprofit and Voluntary Sector Quarterly, 31(4), 525-548.

Brudney, J.L., \& Kellough, J.E. (2000). Volunteers in state government: Involvement, management, and benefits. Nonprofit and Voluntary Sector Quarterly, 29(1), 111-130.

Statistics Canada (2012). Caring Canadian, Involved Canadians: Tables Report 2010. Catalogue No. 89-649-X. Ottawa: Ministry of Industry.

Chum, A., Mook, L., Handy, F., Schugurensky, D., \& Quarter, J. (2013). Degree and direction of paid employee/volunteer interchange in nonprofit organizations. Nonprofit Management and Leadership, 23(4), 409-426. 


\section{Mook, Farrell, Chum, Handy, Schugurensky, \& Quarter (2014)}

Cook, S., \& Speevak Sladowski, P. (2013). Volunteering and older adults. Ottawa, ON: Volunteer Canada. URL: http://volunteer.ca/content/volunteering-and-older-adults-final-report [October 28, 2013].

Handy, F., \& Brudney, J. (2007). When to use volunteer labor resources? An organizational analysis for nonprofit management. Vrijwillige Inzet Onderzocht (VIO, Netherlands), 4, 91-100.

Handy, F., Mook, L., \& Quarter, J. (2008). Interchangeability of paid staff and volunteers in nonprofit organizations. Nonprofit and Voluntary Sector Quarterly, 37(1), 76-92.

Handy, Femida, \& Srinivasan, Narasimhan. (2005). The demand for volunteer labour: A study of hospital volunteers. Nonprofit and Voluntary Sector Quarterly, 34(4), 491-509.

Haski-Leventhal, D., Meijs, L.C.P.M., \& Hustinx, L. (2010). The third party model: Enhancing volunteering through governments, corporations and educational institutes. Journal of Social Policy, 39(1), 139-158.

Haski-Leventhal, D., Hustinx, L., \& Handy, F. (2011). What money cannot buy: The distinctive and multidimensional impact of volunteers. Journal of Community Practice, 19(2), 138-158.

Lapierre, D. (2013). Baby boomers - your new volunteers: Rethinking the voluntary's sector approach to engaging baby boomer volunteers. Ottawa, ON: Volunteer Canada. Presentation to the Silver Economy Summit, Halifax, May 23-24. URL: http://www.silvereconomysummit.ca/uploads/files/DonLapierre_ Volunteerism.pdf [October 28, 2013].

Lohr, S. (1999). Sampling: Design and analysis. Pacific Grove, CA: Duxbury Press.

Mehta, Cyrus R., \& Patel, Nitin R. (1995). Exact logistic regression: Theory and examples. Statistics in medicine, 14(19), 2143-2160.

Meijs, L.C.P.M., Tschirhart, M., Ten Hoorn, E.M., \& Brudney, J.L. (2009). Effect of design elements for corporate volunteers on volunteerability. The International Journal of Volunteer Administration, 26(1), 23-32.

Pfeffermann, D. (1996). The use of sampling weights for survey data analysis. Statistical methods in medical research, 5(3), 239-261.

Raghunathan, T.E., Solenberger, Peter W., \& Van Hoewyk, John. (2002). IVEware. Ann Arbor, Ml: Survey Methodology Program, Survey Research Center, Institute for Social Research, University of Michigan. URL: http://www.isr.umich.edu/src/smp/ive/

Rubin, D.B. (2004). Multiple imputation for nonresponse in surveys. Hoboken, NJ: Wiley.

Schafer, J.L., \& Graham, J.W. (2002). Missing data: Our view of the state of the art. Psychological Methods, 7(2), 147-177. 


\section{ABOUT THE AUTHORS / LES AUTEURS}

Laurie Mook is Assistant Professor in the School of Community Resources and Development at Arizona State University, Phoenix, Arizona. Email: Imook@asu.edu .

Eddie Farrell is Research Coordinator for the Centre for Research on Inner City Health at St. Michael's Hospital, Toronto. Email: eddie.farrell@utoronto.ca .

Antony Chum is a research scientist at the London School of Hygiene and Tropical Medicine, London. Email: antony.chum@utoronto.ca .

Femida Handy is Professor in the School of Social Policy \& Practice at the University of Pennsylvania. Email: fhandy@sp2.upenn.edu .

Daniel Schugurensky is Professor in the School of Public Affairs and the School of Social Transformation at Arizona State University, Phoenix, Arizona. Email: dschugur@asu.edu .

Jack Quarter is Professor in the Department of Leadership, Higher, and Adult Education at the Ontario Institute of Studies in Education of the University of Toronto, and Co-Director of the Social Economy Centre of the University of Toronto. Email: jack.quarter@utoronto.ca . 